\title{
OWNERSHIP STRUCTURE ON CORPORATE SOCIAL RESPONSIBILITY DISCLOSURE IN INDONESIA
}

\author{
JUSTIN GEMA PRASETIO \\ ASTRID RUDYANTO \\ Trisakti School of Management, Jl. Kyai Tapa No. 20, Grogol, Jakarta, Indonesia \\ justingema@gmail.com, astrid@stietrisakti.ac.id
}

\begin{abstract}
The objective of this research is to find empirical evidence about the effect of ownership structure on corporate social responsibility disclosure. This research uses non-financial companies that consistently listed in Indonesia Stock Exchange from the year 2013 to 2017. Samples are obtained using purposive sampling method, in which 62 companies listed meet the sampling criteria; resulting 310 data available are taken as sample. Multiple linear regression and hypothesis test are used as data analysis method of this research. This research result shows that managerial ownership positively affect corporate social responsibility disclosure, while other ownerships (foreign ownership, institutional ownership and government ownership) have no effect on corporate social responsibility disclosure. The result indicates that reducing agency problem with increased managerial ownership is effective on increasing corporate social responsibility disclosure in Indonesia.
\end{abstract}

Keywords: Ownership structure, corporate social responsibility disclosure, agency theory, Indonesia

Abstrak: Tujuan penelitian ini adalah untuk memperoleh bukti empiris mengenai dampak struktur kepemilikan perusahaan terhadap pengungkapan tanggung jawab sosial. Penelitian ini menggunakan seluruh perusahaan nonkeuangan yang terdaftar di Bursa Efek Indonesia tahun 2015 - 2017. Sampel dipilih menggunakan purposive sampling, dimana 62 perusahaan non-keuangan memenuhi kriteria dan menghasilkan 310 data tersedia untuk dijadikan sampel. Penelitian ini menggunakan regresi linier berganda dan pengujian hipotesis sebagai bagian dari analisis data. Hasil dari penelitian ini menunjukkan bahwa hanya kepemilikan managerial yang memiliki pengaruh terhadap tanggung jawab social perusahaan, sedangkan kepemilikan lainnya (kepemilikan asing, kepemilikan institusi dan kepemilikan pemerintah) tidak memiliki pengaruh terhadap perusahaan non-keuangan di Bursa Efek Indonesia.

Kata kunci: Struktur kepemilikan, pengungkapan tanggung jawab sosial perusahaan, teori keagenan, Indonesia

\section{INTRODUCTION}

The urgency of making corporate social responsibility disclosure is recognized since the emergence of legitimacy theory. According to legitimacy theory, companies need to disclose their corporate social responsibility activities to get legitimacy from stakeholders. Companies need to get legitimacy to assure their business sustainability. As corporate social responsibility disclosure is crucial, corporate owners are trying to increase corporate social responsibility disclosure. However, not all types of owners can increase corporate social responsibility disclosure effectively. This 
paper analyzes which type of owners can increase Indonesian companies' social responsibility disclosure effectively.

In Indonesia, listed companies are mandated to make corporate social responsibility disclosure (UU No.40/-2007). However, there is no standard of the type of information that should be disclosed in corporate social responsibility disclosure and to what extent they should disclose. Thus, the extent of corporate social responsibility disclosure depends on corporate owners' decision.

Previous researches have analyzed the effect of corporate ownership on corporate social responsibility disclosure (Sufian and Zahan 2013, Swandari and Sadikin 2011, Al-Garmh and Al-Dhamari 2016). However, existing researches only analyze several types of corporate ownership. For example, Sufian and Zahan (2013) analyze foreign ownership; Swandari and Sadikin (2011) analyze managerial ownership, institutional ownership, and foreign ownership; Al-Garmh and Al-Dhamari (2016) analyze government ownership. Because the types of corporate owners in Indonesia are diverse, it is important to analyze the effect of all types of corporate ownership on corporate social responsibility disclosure. Analyzing just several types of ownership will give partial understanding on the effect of types of ownership on Indonesian companies' social responsibility disclosure. Thus, the purpose of this paper is to get empirical evidence of the effect of all types of owners (foreign ownership, managerial ownership, institutional ownership, government ownership) on corporate social responsibility disclosure.

\section{Legitimacy Theory}

The legitimacy theory says that companies are bound by social contracts that represent the explicit or implicit expectations held by the society regarding how an organization should operate (Deegan and Blomquist, 2006). In order to survive in the society where it is located, the organization, in this case is a company, must meet society expectations. If the company does not meet the expectations, the company is threatened by its legitimacy (Dowling and Pfeffer, 1975). As a result, the company cannot continue its operations due to community demands to meet its expectations.

Corporate social responsibility is one way to gain corporate legitimacy. Although the community, including the government, has demanded and required companies (listed on the Indonesia Stock Exchange) to carry out social responsibility and disclose it, the content of the disclosure of social responsibility is not regulated. Companies must express more than the expectations of society to get legitimacy.

\section{Agency Theory}

Agency theory is a theory that defines the relation between the principal and agent. Jensen and Meckling (1976) define the relationship between agent and principal as a contract under which one or more persons (the principal) engage another person (the agent) to perform some service on their behalf, which involves delegating some decision making authority to the agent. The problems in agency model are with the separation of ownership and control of the company that can make managers only serve their own interests. If the owners of the corporation are not directly involve in managing the company, it will be hard for them to spend their time monitoring and evaluating managerial decisions.

Oh et al. (2011) argue that even if some minor shareholders were willing to monitor managerial decisions, they would not have any means of affecting corporate decision making because they would not have the voting power on the board. However, it is expected more active monitoring and intervention of shareholders into corporate decision making when some group of large shareholders own 
significant amounts of equity. These shareholders include the foreign and domestic institution, company management, and government who owns share in the company. According to Sari et al (2011), CSR activity can bring benefit for management in ways that they can disclose company CSR program in order to get positive review from the shareholders.

\section{Foreign Ownership and Corporate Social Responsibility Disclosure}

Foreign ownership brings the practice of Western-style management practice. The current trends of corporate social responsibility implementation have been largely influenced by Western-style management practice (Oh et al. 2011). Thus, it is assumed that foreign owners increase level of social engagement. As level of social engagement increases, the level of corporate social responsibility disclosure also increases. In addition, foreign investors are likely to choose an investment that can reduce or avoid legitimacy risks (Lee et al. 2017). Therefore, foreign investors will push companies to make social responsibility activities. Because of high information asymmetry faced by most foreign investors, foreign investors will push companies to disclose their social responsibility activities as complete as possible. Previous researches find that foreign ownership has positive association with corporate social responsibility disclosure (Oh et al. 2011, Dissanayake et al. 2016, Said et al. 2009)

$\mathrm{H}_{1}$ : Foreign Ownership has positive effect on Corporate Social Responsibility Disclosure

\section{Managerial Ownership and Corporate Social Responsibility Disclosure}

Managerial ownership will able to reduce agency conflicts that arise between shareholders and managers since both the agent and principal interest are aligned (Paek et al 2013). According to agency theory, managers have their own interest which may not increase shareholders' wealth (Jensen and Meckling 1976). If the managers own significant equity, they are more likely to make decisions maximizing the shareholders' value (McConnell and Servaes 1990). Because corporate social responsibility increases companies' legitimacy, corporate social responsibility increases firm value (Orlitzky et al. 2003). In order to get legitimacy, companies should disclose their corporate social responsibility activities as much as possible. Previous researches find that managerial ownership has positive association with corporate social responsibility disclosure (Susanto 2019, Khan et al 2013, Said et al 2009).

$\mathrm{H}_{2}$ : Managerial Ownership has positive effect on Corporate Social Responsibility Disclosure

\section{Institutional Ownership and Corporate Social Responsibility Disclosure \\ Institutional ownership itself refers to} the share ownership in a company by institutional investor like insurance company, bank, pension fund, and other companies (Nuraina 2012). Because institutional ownership has substantial power voting power, institutional ownership is influential in companies' decision making (Susanto \& Joshua 2018, Shleifer and Vishny 1997). Because institutional owners often own significant ownership in companies and cannot easily sell their shares, they are likely to be more attentive to the firm's strategic decisions than other shareholders. Because institutional owners will have companies' stock in a long time, they will focus on companies' long run strategy. Corporate social responsibility is one of companies' long run strategy. Therefore, institutional owners will increase companies' social responsibility and push them to increase social responsibility disclosure to ensure companies survival. Previous researches find that institutional ownership has positive association with corporate social responsibility disclosure (Majeed et al. 2015, Cox et al. 2017) $\mathrm{H}_{3}$ : Institutional ownership has positive effect on Corporate Social Responsibility.

\section{Government Ownership and Corporate Social Responsibility \\ Indonesian government has been really attentive to corporate social responsibility. It is shown in the increasing rule}


of corporate social responsibility that government has made, such as UU no 40/2007, UU no 28/2007 and the latest is POJK 51/2017. Government-owned companies will be pushed by government to do social responsibility activities and disclose them.

Government has the ability to encourage the management of these companies in making and run program that can benefit its surrounding community and society. Guo et al. (2019), who creates a comparison between state-owned company and non-stateown company in China find that companies which are fully owned and partially owned by government have a significant positive impact on CSR. This result is attributed to the magnitude of government's coercive power as owners in government-owned companies.

According to Rudyanto (2017), government's power as owners affects corporate social responsibility disclosure in two ways. First, government can impose corporate social responsibility regulation more on government owned companies. Second, stateowned companies are more politically-visible companies and thus need more corporate social responsibility disclosure. Previous researches find that government ownership has positive association with corporate social responsibility disclosure (Li and Zhang 2010, Rudyanto 2017, Mohd Ghazali 2007).

Ha4: Government Ownership has effect on Corporate Social Responsibility

\section{RESEARCH METHOD}

The population in this research is nonfinancial companies listed in Indonesia Stock Exchange from the year 2013 to 2017. Sampling selection procedure produces 62 nonfinancial companies, resulting in a total of 310 observations. Table 1 shows the criteria used based on purposive sampling method.

Table 1 Sample Selection Procedures

\begin{tabular}{clcc}
\hline No & Criteria Description & $\begin{array}{c}\text { Number of } \\
\text { Company }\end{array}$ & $\begin{array}{c}\text { Number } \\
\text { of Data }\end{array}$ \\
\hline 1 & $\begin{array}{l}\text { Non financials companies that consistently listed in } \\
\text { Indonesia Stock Exchange from 2013 to 2017 }\end{array}$ & 393 & 1965 \\
2 & $\begin{array}{l}\text { Non financials companies whose fiscal period do not } \\
\text { end on 31 December }\end{array}$ & $(5)$ & $(25)$ \\
3 & $\begin{array}{l}\text { Non financials companies who do not publish annual } \\
\text { reports consistently from 2013 to 2017 }\end{array}$ & $(3)$ & $(15)$ \\
4 & $\begin{array}{l}\text { Non financials companies that do not use Indonesian } \\
\text { Rupiah consistently from 2015-2017 }\end{array}$ & $(78)$ & $(390)$ \\
5 & $\begin{array}{l}\text { Non-financial companies that are not consistently } \\
\text { profitable during the period of 2013 to 2017 }\end{array}$ & $(117)$ & $(585)$ \\
\hline & Final Sample & 62 & 310 \\
\hline
\end{tabular}

In order to measure corporate social responsibilities, this research uses corporate social responsibility index which has been used in previous research. The index is based from prior study by Khan et al. (2013) that applied a list of 20 CSR items with 5 categories which are community involvement (3), environmental (1), employee information (9), product and service information (6), and value added information (1).
A dichotomous procedure is applied: if an item is disclosed in the CSR information, the company will be given score 1 and 0 if it is not disclosed. Foreign ownership is the portion of the company that owned by foreign institutions (Swandari and Sadikin 2017). Managerial ownership is the total percentage of the company shares that are being held by the manager of that same company (Swandari and Sadikin 2017). The 
institutional ownership is the percentage of ownership owned by the local Institutions such as insurance company, pension fund, and others type of company (Nuraina 2012).

Government share ownership is the number of stocks owned by the government. By owning of these stocks, government have the ability to put key figures that can affect the company's decision making (Hartikayanti and Siregar 2018). Based on studies by Said et al. (2017), government ownership is measured by the proportion of ordinary shares owned by the government.

This study uses companies' financial characteristics as control variables. The financial characteristics used as control variables are firm size, profitability, and leverage (Oh et al 2011, Rudyanto 2017). Firm size is calculated with the natural log of total assets (Swandari and Sadikin 2017) Profitability is measured by ROA (Swandari and Sadikin 2017). According to Moussu and Ohana (2016), leverage can be measured with debt ratio which is calculated from total debt divided by the total asset.

This study uses multiple regression model to test the effect of corporate ownership on corporate social responsibility disclosure. This study uses $5 \%$ error to decide the effect of independent variables on dependent variable. Multiple regression model used is as follow:

CSR $=\alpha+\beta 1($ FOREIGN) $+\beta 2($ INST) $+\beta 3($ MNJ) $+\beta 4(\mathrm{GOV})+\beta 5(\mathrm{AGE})+\beta 6(\mathrm{LNSIZE})+$ $\beta 7($ PROFIT $)+\beta 8($ LEV $)+\varepsilon$ Information:

a : Intercept

$\beta 1,2,3,4,5,6,7$ : Variable coefficients

$\begin{array}{ll}\text { CSR } & : \text { CSR index } \\ \text { FOREIGN } & : \text { Foreign Ownership } \\ \text { MNJ } & : \text { Managerial Ownership } \\ \text { LNSIZE } & : \text { Firm Size } \\ \text { PROFIT } & : \text { Profitability } \\ \text { LEV } & : \text { Leverage } \\ \text { AGE } & : \text { Firm Age } \\ \mathrm{e} & : \text { Error }\end{array}$

\section{RESULT AND DISCUSSION}

Table 2 describes descriptive statistic result and Table 3 describes multiple regression test result. Descriptive statistic result shows that percentage of managerial ownership in the sample is really small, only $2 \%$ on average. The maximum value of government ownership is $72 \%$. However, the average is just $4 \%$. These numbers show that there are just a few companies having government ownership but the magnitude of government ownership is huge in those companies. The other types of ownership are distributed evenly.

Before doing multiple regression test, this study has performed classical assumption tests and there is no classical assumption problem. Table 3 shows multiple regression test result. Foreign ownership has the significant value of 0,074 which is more than error $(a=0,05)$. The result shows that $\mathrm{Ha}_{1}$ is not accepted, which means foreign ownership (FOREIGN) do not affect corporate social responsibility disclosure. Most of the studies show that foreign ownership influences on CSR. However studies in Indonesia show otherwise. Research by Swandri and Sadikin (2017) with same conclusion explain that foreign investor feels indifferent towards CSR since they only invest in Indonesia company for mere economic benefit. Park et al. (2014) also argued that multinational companies with foreign direct investment activities are often too vitalized and excessive with their focus to dominate the market they enter. Because of that, CSR becomes an aspect that considered less by the foreign institution. Foreign investors usually own a considerable portion of equity in the company they invest in and based on stakeholder salience theory, stakeholders with more power are likely to have a greater influence on asserting their interest to the management. 
Table 2 Descriptive Statistic Result

\begin{tabular}{cccccc}
\hline Variable & $\mathrm{N}$ & Minimum & Maximum & Mean & Std. Deviation \\
\hline CSR & 310 & 0,25 & 0,95 & 0,661 & 0,162 \\
LNSIZE & 310 & 25,62 & 32,92 & 28,85 & 1,675 \\
PROFIT & 310 & 0,045 & 41,502 & 7,424 & 7,041 \\
LEV & 310 & 7,382 & 122,019 & 45,377 & 20,222 \\
FOREIGN & 310 & 0,000 & 93,784 & 20,414 & 24,801 \\
MNJ & 310 & 0,000 & 33,844 & 2,804 & 4,956 \\
INST & 310 & 0,000 & 91,130 & 46,967 & 26,644 \\
GOV & 310 & 0,000 & 72,405 & 4,762 & 16,931 \\
AGE & 310 & 1 & 36 & 15,79 & 9,074 \\
\hline
\end{tabular}

Table 3 Multiple Regression Test Result

\begin{tabular}{ccccc}
\hline Variable & Coef. & Sig. & Decision & Conclusion \\
\hline FOREIGN & 0,001 & 0,074 & $\mathrm{Ha}_{1}$ Not Accepted & No Effect \\
MNJ & 0,007 & 0,000 & Ha $a_{2}$ Accepted & Has Effect \\
INST & -0.001 & 0,246 & $\mathrm{Ha}_{3}$ Not Accepted & No Effect \\
GOV & 0,001 & 0,197 & $\mathrm{Ha}_{4}$ Not Accepted & No Effect \\
AGE & 0,000 & 0,651 & & \\
LNSIZE & 0,046 & 0,000 & & \\
PROFIT & 0,002 & 0,167 & & \\
LEV & 0,000 & 0,253 & & \\
Adjusted R2 & & 0,286 & & \\
F & & 16,495 & & \\
Sig & & 0,000 & &
\end{tabular}

Dependent Variable: CSR

Source: Data output SPSS 23

Managerial ownership (MNJ) has the significant value of 0,000 which is less than error $(a=0,05)$. The result shows that $\mathrm{Ha}_{2}$ can be accepted, which means managerial ownership (MNJ) have effect on corporate social responsibility disclosure. With the manager having a significant portion of equity, theirs interest will become aligned with the interest that company owners normally have. Soliman et al. (2012) mention good management theory implies that firm value will increase as the company socially become more responsible and since the manager interests are aligned with company owner, it is in the managers best interest for the company value to keep growing over the time. By relying on this notion, the increase of firm value will end up becoming an incentive for managers to more active in engaging CSR activity.

The variable institutional ownership (INST) has the significant value at 0.246 which is more than the value of alpha $(\alpha=0,05)$. The result shows that $\mathrm{Ha}_{3}$ is not accepted, which means institutional ownership does not affect corporate social responsibility disclosure. It is because institutional investor will more indifferent if the company which they invest in are taking action that they deem unnecessary. While institutional investors do not oppose CSR program, they are more interested in fair business practice and product improvement as a 
factor in making investment decisions (Swandri and Sadikin 2017, Teoh and Shiu 1990).

Government ownership has the significant value of 0,197 which is more than the value of alpha $(\alpha=0,05)$. The result shows that $\mathrm{Ha}_{4}$ cannot be accepted, which means government ownership size (GOV) doesn't have effect on corporate social responsibility disclosure. Many studies as mentioned in the previous chapter suggest that government owned companies most likely to have CSR as a result of pressure from their government owners. However, Marcus and Qian (2013) argue that government owned company receive support or even protection from the government agencies that have founded them. CSR can be used by manager to create good image to be selected again by government. However, in Indonesia the process of choosing candidates for management positions need political connection. Knowing government owned companies have the most political power and connection, the need to use CSR activities and disclosure to seek preferred status and associated resources from the government become less needed.

\section{CONCLUSION}

This study analyzes the effect of corporate ownership structure on corporate social responsibility disclosure. By using multiple regression test, this study reveals that managerial ownership is the only ownership that is positively associated with corporate social responsibility disclosure. The result indicates that shareholders cannot control manager to act as shareholders want. Rather, managers need to have the same interest as shareholders to act as shareholders want. The result emphasizes the power of manager in corporate social responsibility research. Future research can analyze further about the role of Indonesian companies' manager in corporate social responsibility disclosure and the type of manager that can increase corporate social responsibility disclosure.

\section{REFERENCES:}

Al-Gamrh, B.A., AL-Dhamari, R.A. 2016. Firm Characteristics and Corporate Social Responsibility Disclosure. International Business Management, 10(18), 4283-4291.

Cox, P., Brammer, S., Millington, A., and Cox, P. 2017. An Empirical Examination of Institutional Investor Preferences for Corporate Social Performance, Journal of Business Ethics, 52(1), $27-43$.

Deegan, C., and Blomquist, C. 2006. Stakeholder influence on corporate reporting: An exploration of the interaction between WWF-Australia and the Australian minerals industry. Accounting, Organizations and Society, 31(4-5), 343-372. https://doi.org/10.1016/j.aos.2005.04.001

Dissanayake, D., Tilt, C., and Xydias-lobo, M. 2016. Sustainability reporting by publicly listed companies in Sri Lanka. Journal of Cleaner Production, 129, 169-182. https://doi.org/10.1016/j.jclepro.2016.04.086

Dowling, J., and Pfeffer, J. 1975. Organizational Legitimacy : Social Values and Organizational Behavior between the Organizations seek to establish congruence. The Pacific Sociological Review, 18(1), 122-136. https://doi.org/10.2307/1388226

Guo, M., Hu, Y., Zhang, Y., and Tian, F. 2019. State-Owned Shareholding and CSR: Do Multiple Financing Methods Matter?-Evidence from China. Sustainability,11(5), 1-15.

Hartikayanti, H. N., and Siregar, I. W. 2018. The Effect of Stock Ownership toward the Corporate Social Responsibility (CSR) Disclosure. KnE Social Sciences, 3(10)

Jensen, M.C., and W.H. Meckling. 1976. Theory of the Firm: Managerial Behavior, Agency Costs and Ownership Structure. Journal of Financial Economics, 3(4), 305-360.

Khan, A., Muttakin, M., and Siddiqui, J. 2013. Corporate Governance and Corporate Social Responsibility Disclosures: Evidence from an Emerging Economy. Journal of Business Ethics, 114(2), 207-223 
Lee, J., Kim, S. J., and Kwon, I. 2017. Corporate Social Responsibility as a Strategic Means to Attract Foreign Investment: Evidence from Korea. Sustainability, 9(11), 2121.

Li, W., and Zhang, R. 2010. Corporate Social Responsibility, Ownership Structure, and Political Interference: Evidence From China. Journal of Business Ethics, 96(4), 631-645.

Majeed, S., Aziz, T., and Saleem, S. 2015. The Effect of Corporate Governance Elements on Corporate Social Responsibility (CSR) Disclosure: An Empirical Evidence from Listed Companies at KSE Pakistan. International Journal of Financial Studies, 3(4), 530-556. https://doi.org/10.3390/ijfs3040530

McConnell, J., and Servaes, H. 1990. Additional evidence on equity ownership and corporate value. Journal of Financial Economics, 27(2), 595-612.

Mohd Ghazali, N.A. 2007. Ownership Structure and Corporate Social Responsibility Disclosure: Some Malaysian Evidence. The International Journal of Business in Society, 7(3), 251-266.

Moussu, C., and Ohana, S. 2016. Do Leveraged Firms Underinvest in Corporate Social Responsibility? Evidence From Health and Safety Programs in US Firms. Journal of Business Ethics, 135, 715-729.

Nuraina, E. 2012. Pengaruh Kepemilikan Institusional dan Ukuran Perusahaan terhadap Kebijakan Hutang dan Nilai Perusahaan (Studi Pada Perusahaan Manufaktur Yang Terdaftar Di BEI). Jurnal Bisnis dan Ekonomi Akuntansi, 18(2), 110-125.

Oh, W. Y., Chang, Y. K., and Martynov, A. 2011. The Effect of Ownership Structure on Corporate Social Responsibility: Empirical Evidence from Korea. Journal of Business Ethics, 104(2), 283-297.

Orlitzky, M., Schmidt, F. L., and Rynes, S. L. 2003. Corporate Social and Financial Performance: A Meta-Analysis. Organization Studies, 24(3), 403-441. https://doi.org/10.1177/0170840603024003910

Paek, S., Xiao, Q., Lee, S., and Song, H. 2013. Does Managerial Ownership Affect Different Corporate Social Responsibility Dimensions? an Empirical Examination of US Publicly Traded Hospitality Firms. International Journal Of Hospitality Management. 34, 423-433.

Park, B. I., Chidlow, A., and Choi, J. 2014. Corporate social responsibility: Stakeholders influence on MNEs' activities. International Business Review, 23(5),966-980.

Rudyanto, A. 2017. State Ownership, Family Ownership, and Sustainability Report Quality : The Moderating Role of Board Effectiveness. Accounting and Finance Review, 2(2), 15-25.

Said, R., Hj Zainuddin, Y., and Haron, H. 2009. The relationship between corporate social responsibility disclosure and corporate governance characteristics in Malaysian public listed companies. Social Responsibility Journal, 5(2), 212-226. https://doi.org/10.1108/17471110910964496

Said, R., Joseph, C., and Sidek, N. Z. M. 2017. Corporate Governance and Corporate Social Responsibility (CSR) Disclosure: The Moderating Role of Cultural Values'. Modern Organisational Governance (Developments in Corporate Governance and Responsibility),12,189-206.

Sari, A.R. and Sukoharsono, E.G. 2013. Pengaruh Kepemilikan Institusional, Komposisi Dewan Komisaris, Kinerja Perusahaan terhadap Luas Pengungkapan Corporate Social Responsibility di dalam Sustainability Report pada Perusahaan Manufaktur yang Terdaftar di BEl. Jurnal Aplikasi Manajemen, 11(3), 481-491.

Sembiring, E.R., 2006. Karakteristik perusahaan dan pengungkapan tanggung jawab sosial: study empiris pada perusahaan yang tercatat di Bursa Efek Jakarta. MAKSI, 6(1), 69-85

Shleifer, A., and Vishny, R. W. 1997. A Survey of Corporate Governance. The Journal of Finance, 52(2), 737-783.

Soliman, M., El Din, M.B. and Sakr, A. 2012. Ownership Structure And Corporate Social Responsibility (CSR): An Empirical Study Of The Listed Companies In Egypt. The International Journal of Social Science, 5(1), 6374

Sufian, M. A., and Zahan, M. 2013. Ownership structure and corporate social responsibility disclosure in Bangladesh. International Journal of Economics and Financial Issues, 3(4), 901-909. https://doi.org/10.1108/14720700710756535

Susanto, Y.K. \& Joshua, D. 2018. Pengaruh tata kelola perusahaan dan Karakteristik Perusahaan Terhadap Pengungkapan Tanggung Jawab Sosial Perusahaan. EKUITAS (Jurnal Ekonomi dan Keuangan), 2(4), 572-590. 
Susanto, Y.K. 2019. Corporate Social Responsibility Disclosure: Corporate Governance and Profitability. South East Asia Journal of Contemporary Business, Economics and Law, 20(1), 39-44.Untari, Lisna. 2010. Effect on Company Characteristics Corporate Social Responsibility Disclosure in Corporate Annual Report of Consumption Listed in Indonesia Stock Exchange. Gudadarma University.

Swandari, F. and Sadikin, A. 2016. The Effect of Ownership Structure, Profitability, Leverage, and Firm Size on Corporate Social Responsibility (CSR). Binus Business Review, 7(3), 315-320.

Teoh, H.Y. and Shiu, G.Y. 1990. Attitudes Towards Corporate Social Responsibility And Perceived Importance Of Social Responsibility Information Characteristics In A Decision Context. Journal of Business Ethics, 9(1), 71-77. 
